\title{
The Theoretical System of Human Rights with Chinese Characteristics
}

\author{
Ying Ren \\ Green Development Law Research Center, Guangdong University of Foreign Studies, Guangzhou, China \\ Email:2052614426@qq.com
}

How to cite this paper: Ren, Y. (2018). The Theoretical System of Human Rights with Chinese Characteristics. Chinese Studies, 7, 210-219.

https://doi.org/10.4236/chnstd.2018.73018

Received: June 24, 2018

Accepted: July 29, 2018

Published: August 2, 2018

Copyright (C) 2018 by author and Scientific Research Publishing Inc. This work is licensed under the Creative Commons Attribution International License (CC BY 4.0).

http://creativecommons.org/licenses/by/4.0/

\begin{abstract}
Human rights discourse and its theoretical system play an irreplaceable role in the history of human civilization. The purpose of this paper is to summarize and discuss the formation of human rights theory system, which consists of three parts. These parts are the background, cultural resources and the establishment of human rights theory system with Chinese characteristics. In the course of development, China has creatively established the idea of striving for national independence and people's happiness, the theory of socialist human rights and legal system, the thought of human rights protection and party building, the notion of human rights and scientific development and the concept of human rights theory system with Chinese characteristics in the new era. These ideas are important milestones in the development of Chinese human rights theory system.
\end{abstract}

\section{Keywords}

Theoretical System of Human Rights, Chinese Characteristics, New Era

\section{Introduction}

In recent years, the theory and practice of human rights with Chinese characteristics have received extensive attention. Cross-cultural human rights exchanges are becoming increasingly prosperous. China has released the report on achieving the Millennium Development goals. China's great contribution to the realization of the right to development has been fully acknowledged by the international community. This large country with a population of nearly 1.4 billion has promoted innovative development, coordinated development, green development and open development on the basis of "people-oriented". At the same time, the concept of shared development and its results are also recognized by people. China's unique path in promoting economic, political, cultural, social 
and environmental rights has made outstanding contributions to safeguarding a just world order and promoting international human rights development.

The study of human rights theory and practice is very rich (Symonides, 2002). From the perspective of literature review, Wm. Theodore de Bary's article, "Asian Values and Human Rights: A Confucian Communitarian Perspective", which was published by Harvard University Press in 1988, discussed the Confucian rights culture. Angle S C.'s article, "Human Rights and Chinese Thought", which was published by Cambridge University Press in 2002, explored the origin of human rights concept in China. Other articles, such as "the connotations of human rights under the socialist core value system", "on the relationship between human rights protection and the modernization of state governance" and "the socialist rule of law with Chinese characteristics and human rights protection", which were published in the journal of "Human Rights", expounded the basic category of human rights in China, the way of human rights development and the protection of human rights under the rule of law. However, the systematic theoretical analyses of human rights issues, especially the discussion of human rights cultural resources and the study of the human rights theory system with Chinese characteristics, remain to be further deepened. In 2018, the nineteenth National Congress of the Communist Party of China declared that "the socialism of Chinese characteristics entered a new era". At the moment, reviewing the development of the theory of human rights with Chinese characteristics from the perspective of history and analysis is an important embodiment of the sustained efforts to achieve the happiness of the people, and the effort devoted to the development and common prosperity of the world. Therefore, this article analyzes the historical origin, establishment and development of the system of human rights in China with a view to the future, hoping to provide valuable reference for future study.

Specifically, the cultural resources of the theoretical system of human rights with Chinese characteristics combine the value of basic human rights, the traditional cultural resources and the practice of human rights at a specific historical stage to form a scientific and complete structure. The establishment of human rights theory system with Chinese characteristics has played a positive role in promoting the development of rule of law and human rights policy. The innovation and development of the theoretical system of human rights with Chinese characteristics is a preliminary exploration of human rights discourse and an important theme of human rights law's advancing with the times (Wheeler, 2005). The reform of human rights practice in China has promoted the innovation and development of human rights construction, which is an important embodiment of the construction of human rights theory system with Chinese characteristics at the level of discourse practice. This theoretical system structure fully reflects the harmonious relationship between man, nature and society, and is a major breakthrough in the framework of knowledge model and strategic layout. Under the background of emphasizing the construction of a country 
ruled by law and the guarantee of human rights, the research on the basic theoretical system of human rights is particularly important and prominent.

\section{Cultural Resources of the Theoretical System of Human Rights with Chinese Characteristics}

\subsection{Ancient Cultural Resources}

The theory of human rights with Chinese characteristics has gone through the historical endogenous evolution of the concept of human rights. The term "civil rights" appeared in ancient China, but its application in practice had its historical limitations. At the level of economic governance, the historical records of Yuan Dynasty emphasized that people's rights should not be abused. In terms of political rights, the history of the Qing Dynasty recorded that men enjoyed civil rights under the local autonomy clause. In addition, the history of the Qing Dynasty made a comparative analysis of the concept of civil rights in the strategies of governing the country.

In the course of historical development, the concept of civil rights in ancient China was embodied in Huang Zongxi's thought of world interests. He believed that the right should be vested in all the people of the world. The rise and fall of the world was not the rise or fall of a family name, but the happiness of the whole people. These claims emphasized the protection of rights at the level of state governance. On that basis, he suggested two measures. One was to oppose autocratic monarchy and emphasize civil rights. The other was against the private law, advocating the law of the common world and emphasizing the interests of the people. Through these measures, the violation behaviors of the rights of individuals, including property rights, were severely criticized, and the concept of safeguarding the interests of the world was strongly promoted.

On the whole, the ancient Chinese thought on right guarantee was embodied in the ideas of good law, good governance and people-oriented notion. On the one hand, the standard of good law in ancient China mainly included two aspects: concept and practice. The former emphasized that the rule of law must be accepted by the people. Good governance could be achieved through the rule of law. The latter was recorded as the fair enforcement of the law, which was a prerequisite for good law and good governance. A man couldn't be called a good governor if he lacked care for civil affairs. On the other hand, good governance could be achieved through people-oriented reforms. The book of the Han Dynasty recorded that people often wanted to govern well, but they couldn't do it. That was because they ignored reform and improvement. Actually, in order to meet the needs of the people, good governance requires that the governing body should abolish the strict laws harmful to the people.

\subsection{Contemporary Theoretical Basis}

The founding of the People's Republic of China opened a new chapter in the cause of human rights protection and established the guiding position of Marxist 
theory of human rights with the ultimate goal of human freedom and all-round development. In fact, the materialist view of human rights is the most important foundation of the theory of human rights with Chinese characteristics and the logical starting point of the localization of Marx's theory of human rights. Marx pointed out that rights couldn't exceed the economic structure and cultural development of a society dominated by the economic situation. Concretely speaking, materialistic view of human rights is mainly embodied in two aspects. The first is material constraint. The overall development of human beings is based on production. But market freedom is not a sufficient condition for human freedom. In the stage of material dependence in the development of human history, the individual is even less free. Because people are more dominated by the power of things. This requires that we should avoid egoistic people's rights that are divorced from human nature and social attributes. The second is cultural restriction. From the embodiment of cultural constraint in the field of human rights protection, cultural backwardness and the revival of bureaucracy will restrict the superiority of relevant system construction. Further analysis, the legal recognition of free rights is an important guarantee for the construction of the human rights theory with Chinese characteristics. Freedom is the inherent right of human beings. And law is only applicable to human behavior. As Marx's criticism of the social reality in the sixth Rhine debates, the news freedom is the basis of all freedoms. This is an important embodiment of the concept of freedom and rights. Therefore, we should maintain equal freedom and the rights of people, and avoid the alienation of freedom and legal relations. At the same time, the relationship between law and freedom is like gravity and movement. Freedom is stipulated in the form of universality and certainty. And we should prohibit all violations of freedom, and guarantee the actual existence of human freedom. In other words, the appeal to human rights originates from the legal requirements for freedom. The rationality of law abiding and governance has been realized organically.

All work related to the building and protection of human rights should ultimately return to the goal of human freedom and full development. That is adhering to the people-oriented notion, the fundamental interests of the people, the people's freedom and comprehensive development as the lofty goal. Achieving this goal requires tangible development and progress in order to promote equity and justice (including a just and equitable international order). The development model with welfare, order, justice and equity as the core should be devoted to harmonious governance. Only when equal rights and freedoms are obtained in economic and social aspects can the duality of human rights and civil rights be truly resolved, and the essential unity of human rights and civil rights be realized. Only by unifying the real freedom in the economic and social fields with the protection of political rights can we truly realize the all-round rejuvenation of human beings, and obtain substantive equal rights. Taking realistic man as the starting point of social production practice, the unity of universality and 
particularity of human rights is realized, and the organic unity of human nature and social attribute is embodied. Therefore, we should strive to realize individual equality, freedom and collective development right, take the right of existence and development as the core content, and realize the unification of legal form and practice form in the specific historical stage. Proceeding from the specific economic and social conditions, China has promoted the ultimate realization of the all-round development of human beings, as well as the overall protection of economic, political, cultural, social and ecological rights. On this basis, we can explore higher levels of human rights protection.

\section{The Establishment of the Theoretical System of Human Rights with Chinese Characteristics}

\subsection{The Struggle for National Independence and People's Well-Being}

The realization of people's happiness is based on national independence. Therefore, the starting point of the construction of Chinese human rights theory system is to strive for national independence. This is also the focus of the thought of specific freedom and people's freedom. The thought of Mao Zedong opened the way of people's revolution with the goal of people's rights protection, and developed the human rights thought of people as masters of their own country, striving for national sovereignty and national liberation so as to safeguard the people's rights to exist. He called for the struggle for national independence, civil rights, freedoms and the well-being of the people, and elaborated on equal human rights, economic rights, the right to vote and freedom of expression, assembly, association and belief. At the same time, China passed a series of regulations (including the 1954 Constitution) to ensure that workers, farmers, soldiers and all working people have the right to elect representatives. This laid a solid foundation for the Sinicization of Marxist human rights thought. Based on the basic principles of Marxism, Mao Zedong emphasized the restriction of economic base and basic political system on specific human rights (Chan, 2013). Only by safeguarding the people's freedom can we truly liberate the working people. On one hand, the ownership of the people is an important prerequisite for the realization of human rights equality and personal freedom. This is also the proper meaning of civil rights so that people throughout the country enjoy freedom of speech, political rights, property rights, education and the right to work. On the other hand, the concepts of serving the people wholeheartedly, unifying the cause of the country with the interests of the people, taking power as the realistic basis for safeguarding human rights, ensuring that the design and construction of the entire system originate from, rely on, and serve the people.

\subsection{Socialist Theory of Human Rights and Legal System}

The establishment of socialism with Chinese characteristics and the promotion of reform and opening up have laid an important foundation for the protection 
of human rights in China, and are the key links in the establishment of the theoretical system of human rights with Chinese characteristics (Deshun, 2002). Deng Xiaoping's theory of human rights is based on the pioneering work of socialism with Chinese characteristics. He believes that human rights are for the benefit of the vast majority of the people, and human rights should belong to the overwhelming majority. He stressed that Chinese modernization drive must be based on its own reality. In fact, democracy in China is people's democracy, which is an important prerequisite for achieving common prosperity and opposing extreme individualism and anarchism. Therefore, we should pay attention to the coordination of individual and collective interests, local interests and overall interests, temporary interests and long-term interests. At the same time, on the basis of developing productive forces, eliminating polarization, and realizing common prosperity and all-round development of the people, we should promote the realization of the right to survival and development as the main human rights. Deng Xiaoping theory is based on emancipating the mind, seeking truth from facts and socialist modernization. These ideas guide the development direction of Chinese human rights discourse. In addition, the development of socialist market economy as the center of socialist modernization has also been affirmed. Thus the connotation of historical materialism of human rights based on material basis should be modernized. This has laid the foundation for the effective operation of the socialist market economy. The development of socialist market economy aims at common prosperity, allowing some regions to develop first and avoiding polarization through redistribution. In other words, the liberation and development of socialist modernization and productive forces have laid a solid foundation for the realization of human rights, equality and freedom, and provided realistic guarantee for the improvement of the living standard of people and the construction of the theoretical system of human rights.

On this basis, the thoughts of rights and legal system embody the origin of rights, economic construction, democracy and the essence of legislation. On the one hand, the democratic system of human rights should be established on the basis of institutionalization and legalization, which is the basic way to guarantee people's democratic rights. On the other hand, the relationship between rights and obligations should be fundamentally emphasized as the political and legal manifestation of interest relations. In practice, the advanced nature of this thought is concentrated on the formulation and promulgation of the Constitution of the People's Republic of China in 1982. The second chapter stipulates the rights and obligations of citizens, and lays the foundation of materialist dialectics for the whole system of human rights law. Through this process, the basic structure of socialist human rights legal system has formed.

\subsection{Human Rights Protection and the Party Construction}

At the end of the 20th century, the cause of international socialism suffered setbacks. In this period, the focus of human rights construction was to establish a 
high degree of consistency between the fundamental interests of the Party and the people and to consolidate the road of development of socialism with Chinese characteristics. Jiang Zemin put forward the important thought of "three represents", which included representing the requirements of the development of China's advanced social productive forces, the direction of the advance of China's advanced culture and the fundamental interests of the overwhelming majority of the Chinese people. He also defined the basic ways for the close integration of collective human rights and individual human rights, for coordinated development and the integration of the universality of human rights with national conditions. Relevant administrative organs and research institutions put forward the bill of "constructing Marxist theory system of human rights" (Shen, 2015), and great progress in theoretical research, policy formulation, publicity and education was made.

At the same time, on the basic level of normalizing the construction of the ruling party, we should promote the development of human rights. In 1999, the Constitution Amendment Law established the overall strategy of governing the country according to law. In 2004, the Constitution Amendment became the normative basis for the inclusion of human rights in the Constitution. The development of such legislation also contributed to the establishment of a governance framework that combined the rule of law with the rule of virtue, and makes human rights, human dignity and the fundamental interests of the overwhelming majority of the people the fundamental pursuit and core objective of governance. On this basis, respecting and protecting human rights became an important standard for political party construction and improvement of ruling ability. Through this process, the important thought of "three represents" unified the party building with the fundamental interests of the people, and formulated a series of human rights rules and regulations of the party. Political party governance and human rights protection are highly valued. Therefore, the Party's rules and regulations have become the basic guarantee of respecting and protecting human rights. The "three represents" have also been written into the Party's Constitution, and the Party's discipline has been continuously improved, fully safeguarding the rights and freedoms of the people.

\subsection{Harmonious Notion of Human Rights Construction and Scientific Development}

With the development of social construction, the contradictions and conflicts of social interests and values gradually appear. It is the most urgent task to solve this contradiction effectively and combine new forces to promote the development of society. Hu Jintao puts forward that harmony is the essential attribute of socialism, and further clarifies that the road of economic and social construction is scientific development, and the fundamental development lies in people-oriented notion. These suggestions have opened up a new field for the construction of China's human rights theoretical system, emphasizing the promotion of human 
rights practice in a harmonious spirit, the unification of human rights protection and individual self-discipline, and the harmonious development of the relationship between individual and government in order to provide strong social support for the construction of human rights (Heath, 1998). In fact, the state and society are leading a new dimension of harmonious relations in order to overcome the "irreversible, insurmountable contradictions and limitations" contained in the concept of human rights since its inception. This has also laid an important ideological foundation for the construction of a theoretical system of human rights with Chinese characteristics.

Through these efforts, we set up scientific outlook on development to establish a people-oriented concept of development. This concept emphasizes the protection of the people's rights and interests from the economic, political, cultural, social and ecological aspects. The human rights values of people-oriented persist in the development of the people, the development depending on the people and the development results shared by the people. The value concept of human rights mainly includes three aspects. First, we should attach great importance to equal participation and development for all. The year 2008 marked the sixtieth anniversary of the Universal Declaration of Human Rights. In a letter to the China Institute of Human Rights, Hu Jintao made it clear that we should adhere to the people-oriented principle of respecting and protecting human rights as the basic principle of governance. Second, from the height of the guiding ideology, the fundamental interests of the vast majority of the people should be taken as the starting point and foothold of the scientific outlook on development. The interests of the masses are divided into the watershed of historical materialism and idealist historical view. Third, we should correctly handle the relationship between power and rights, executive power for the people, and bring benefits for people. At the same time, development is an important prerequisite to meet the growing material and cultural needs of the people, to guarantee the realization of basic human rights, to coordinate the construction of human rights in the economic, political, cultural and social fields and to realize the freedom of everyone.

\subsection{Human Rights View of Socialism with Chinese Characteristics in the New Era}

With the establishment of the concept of people-centered development, General Secretary Xi Jinping's thought of governing and managing politics has been fully affirmed by the international community, and has opened a new chapter in the history of human civilization. People-centered development has become an important basis for the new era of socialist human rights with Chinese characteristics. The core of people-centered discourse innovation and human rights development is to transform adversarial discourse into harmonious discourse on the basis of people's fundamental interests. The theoretical innovation of human rights centered on the people is a practical exploration based on the unity of the 
fundamental interests of the people and the lofty goal of human freedom and all-round development. It replaces power politics with equal negotiation, opposability with harmony, and discourse hegemony with equal discourse. The guidance of the people-centered concept of development is holistic and long-term, which embodies the contribution of Chinese human rights discourse to the world.

At the same time, General Secretary Xi Jinping proposed the concept of building a community of human destiny, which reflected the core spirit of human rights development. In fact, there is a mutually supportive relationship between a common destiny of human society and human rights theory system, which forms a scientific governance logic. Constructing the community of human destiny is the goal of the construction of human rights theory system. The category of human rights in China, proceeding from the specific economic and social conditions, has promoted the ultimate realization of the all-round development of human beings, and embodied the natural and social attributes of human beings, as well as the unity of the universality and particularity of human rights. The core is the fundamental right to survival and development. This is an important foundation for building a community of human destiny. China's human rights theory is also based on the overall promotion of human rights and the rule of law, forming a systematic guarantee of human rights and the rule of law. These characteristics are of great significance to the development and protection of human rights and the construction of human destiny community. China's human rights protection has also established a basic category operation mechanism characterized by the organic unification of rights and obligations, including the human rights legislation system with Chinese characteristics and the implementation system of human rights ruling of law. At the same time, we are working hard to carry out a fair assessment of human rights. China's human rights indicators are based on the reality of human rights, take the modernization of the interactive mechanism between domestic human rights indicators and international human rights assessment as the path, and establish a judgment standard with the common development of mankind as the core. This also provides the fair evaluation system support for the construction of the human destiny community.

\section{Conflicts of Interest}

The authors declare no conflicts of interest regarding the publication of this paper.

\section{References}

Chan, P. C. W. (2013). Human Rights and Democracy with Chinese Characteristics? Human Rights Law Review, 13, 645. https://doi.org/10.1093/hrlr/ngt034

Deshun, L. (2002). The Theoretical Cornerstone of Socialism with Chinese Characteristics. Social Sciences in China, 23, 96.

Heath, B. (1998). Civil Society with Chinese Characteristics? The Australian Journal of 
Chinese Affairs, 39, 69.

Shen, T. X. (2015). The Development of Human Rights Education in China: Characteristics, Problems and Sustainability. Asian Education and Development Studies, 3, 344. https://doi.org/10.1108/AEDS-12-2014-0062

Symonides, J. (2002). Human Rights: Concept and Standards (p. 33). England: Dartmouth Publishing Company Limited.

Wheeler, N. (2005). Modernization Discourse with Chinese Characteristics. East Asia, 22, 3. https://doi.org/10.1007/s12140-005-0012-8 